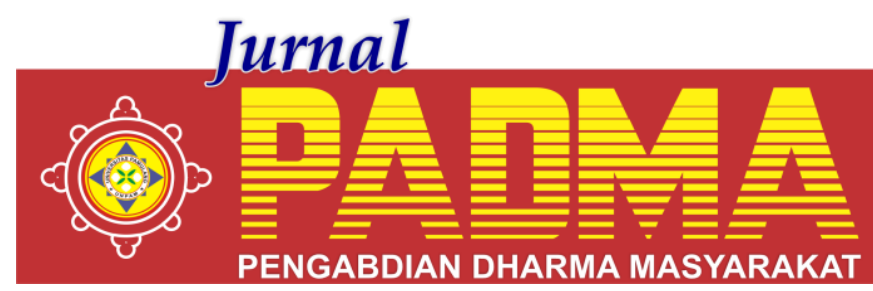

VOLUME I, NOMOR I, JANUARI 2021

\title{
PENYULUHAN DAN PELATIHAN KETERAMPILAN SABLON PIGMENT PASTA MANUAL DI KARANG TARUNA 03 DESA CISAUK
}

\author{
${ }^{1 *}$ Rully Nur Dewanti, ${ }^{2}$ Edi Supriyadi, ${ }^{3}$ Soleh Sofyan, ${ }^{4}$ Denok Sunarsi, ${ }^{5}$ Boy Andika \\ Rachmansyah, ${ }^{6}$ Ahmad Yani \\ Universitas Pamulang, Tangerang Selatan, Banten, Indonesia \\ *dosen01273@unpam.ac.id
}

\begin{abstract}
Abstrak
Sablon adalah teknik cetak saring dengan menggunakan bahan dasar cat tekstil. Pada umumnya dapat dibedakan menjadi dua jenis dalam pegerjaannya, ada yang manual dan juga menggunakan mesin. Pemberdayaan pemuda karang taruna sebagai anggota masyarakat dan masih tergolong sebagai tenaga kerja produktif sangat penting dilakukan, bertujuan untuk menumbuhkan kesadaran dan kemandirian dalam berusaha, sekaligus memperluas lapangan kerja guna meningkatkan pendapatan keluarga dalam usaha mencapai keluarga yang bahagia dan sejahtera. Tujuan kegiatan kewirausahaan adalah untuk memberikan pengetahuan dan pelatihan tentang pembuatan sablon manual sekaligus untuk membantu menciptakan industri kreatif sehingga dapat menciptakan peluang usaha baru. Pelatihan diberikan dalam bentuk ceramah yang dilanjutkan dengan eksperimen langsung dan tanya jawab. Praktek cara pembuatan pasta pigment sablon dan pelatihan proses penyablonan. Remaja karang taruna dibagi dalam beberapa kelompok, kemudian dengan dibimbing Tim pengabdian mempraktekkan sendiri pembuatan produk tersebut. Pelatihan dilaksanakan sampai semua peserta dapat mempraktekkan sendiri
\end{abstract}

Kata Kunci: Sablon, Karang Taruna, Kewirausahaan, Pelatihan

\begin{abstract}
Screen printing is a filter printing technique using textile paint as the base material. In general, it can be divided into two types in the process, some are manual and also use a machine. The empowerment of youth youth groups as members of the community and still classified as a productive workforce is very important to do, aimed at fostering awareness and independence in doing business, as well as expanding employment in order to increase family income in an effort to achieve a happy and prosperous family. The aim of entrepreneurial activities is to provide knowledge and training on manual screen printing as well as to help create creative industries so that they can create new business opportunities. The training is given in the form of lectures followed by direct experiments and questions and answers. Practicing how to make screen printing pigment paste and training on the printing process. Youth youth groups were divided into several groups, then guided by the community service team practiced making these products themselves. The training is held until all participants can practice on their own
\end{abstract}

Keywords: Screen Printing, Youth Organization, Entrepreneurship, Training

\section{PENDAHULUAN}

Sablon adalah salah satu kata yang sangat familiar didengar dalam bisnis fashion. Hal ini disebabkan karena sablon memberikan variasi berbeda dalam hal pembuatan pakaian dan aksesorisnya. Sablon adalah kegiatan mencetak objek dalam bentuk gambar atau tulisan yang dilakukan dengan menggunakan screen atau template di permukaan yang datar dengan media apa saja. Media yang biasanya digunakan dalam sablon ini bisa media yang memiliki daya serap tinggi seperti kain, daya serap menengah seperti spanduk dan daya serap minimal seperti plastik.

Sablon adalah teknik cetak saring dengan menggunakan bahan dasar cat tekstil. Pada umumnya dapat dibedakan menjadi dua jenis dalam pegerjaannya, ada yang manual dan juga menggunakan mesin. Proses cetak sablon menggunakan mesin terbilang lebih cepat dan hasil yang lebih maksimal (Pramono \& Hilmy, 2019). Namun keberadaan cetak sablon mesin juga diimbangi dengan peralatan yang canggih sehingga terbilang cukup mahal dalam penerapannya. Sedangkan cetak sablon 
manual terbilang lebih murah, karena tenaga yang digunakan lebih banyak menggunakan tangan manusia (Maulana, n.d.). Peralatan yang digunakan pun relatif lebih murah dibandingkan dengan menggunakan sablon mesin. Sejatinya peralatan yang digunakan sablon manual dan sablon mesin banyak memiliki kemiripan, karena peralatan sablon mesin mengadaptasi dari proses sablon manual yang telah berkembang terlebih dahulu. Peralatan sablon antara lain: screen, frame, rakel, hairdrier dan hand sprayer.

Sablon adalah salah satu teknik proses cetak yang menggunakan layar (screen) dengan kerapatan tertentu dan umumnya barbahan dasar Nylon atau sutra (silk screen). Layar ini kemudian diberi pola yang berasal dari negatif desain yang dibuat sebelumnya di kertas HVS atau kalkir. Kain ini direntangkan dengan kuat agar menghasilkan layar dan hasil cetakan yang datar. Setelah diberi fotoresis dan disinari, maka harus disiram air agar pola terlihat lalu akan terbentuk bagian-bagian yang bisa dilalui tinta dan tidak.

Istilah cetak saring di Indonesia lebih populer dengan sebutan cetak sablon. Kata sablon berasal dari bahasa Belanda, yaitu Schablon, sehingga dalam bahasa serapan menjadi sablon (Luzar, 2010). Sablon dapat didefinisikan sebagai pola berdesain yang dapat dilukis berdasarkan contoh. Cetak sablon adalah mencetak dengan menggunakan model cetakan atau mal. Cetak saring adalah mencetak dengan menggunakan kain gasa yang dibingkai disebut screen. Proses Pembuatan Cetak saring bisa dilakukan dengan mesin seperti yang dilakukan pada pabrik printing dan bisa dilakukan secara manual seperti yang dilakukan oleh home Industri menengah dan kecil. Teknik pembuatan desain motif dengan cara: tanpa kodatrace atau menggunakan kertas warna gelap dengan kodatrace dan komputer atau teknik sparasi warna (CMYK). Zat warna yang digunakan antara lain zat warna pigmen dan zat warna reaktif, walaupun hamper semua jenis zat warna untuk tekstil bisa digunakan. Kain tekstil yang digunakan hampir semua jenis kain tekstil, dari serat sintetis atau serat alam yang mempunyai permukaan datar bisa disablon dengan menggunakan screen.
Cetak saring atau sablon atau screen printing merupakan bagian dari ilmu grafika terapan yang bersifat praktis. Cetak saring dapat diartikan kegiatan cetak mencetak dengan menggunakan kaingasa/kasa yang biasa disebut screen (Luzar, 2010). Pada umumnya cetak mencetak dilakukan pada setiap benda padat yang datar tetapi dapat juga dilakukan di atas bentuk yang melingkar. Pada prinsipnya cetak mencetak pada berbagai macam benda padat adalah sama. Perbedaannya terletak pada jenis cat/tinta yang digunakan dan jenis produk yang akan dicetak.

Teknologi screenprint diatas kaos katun baru dimulai awal "60-an dan setelah itu barulah bermunculan berbagai bentuk kaos baru, seperti tank top, muscle shirt, scoop neck, v-neck dsb. Berbagai bentuk, gambar, atau kata-kata dalam kaos merupakan pesan akan pengalaman, perilaku dan status sosial. Kaos oblong mengkomunikasikan berbagai lokasi atau identitas sosial: tempat (HRC, Borobudur, Bali, Yogyakarta), bisnis (Coca Cola, Yamaha, Suzuki), tim (MU, Inter Milan), konser atau acara kesenian (Jakjazz), komoditas yang dianggap bernilai (Luzar, 2010), sementara banyak juga yang mengkomunikasikan slogan (kaos-kaos Dagadu, Joger).

Tujuan kegiatan kewirausahaan adalah untuk memberikan pengetahuan dan pelatihan tentang pembuatan sablon manual sekaligus untuk membantu menciptakan industri kreatif sehingga dapat menciptakan peluang usaha baru (Tobroni, 2011).

Proses pemberdayaan masyarakat berarti kemampuan seseorang untuk memahami dan mengendalikan keadaan sosial, ekonomi dan kemampuan yang sangat diperlukan dalam upaya memperbaiki keduduknnya dimasyarakat, dengan kata lain proses pemberdayaan adalah setiap usaha pendidikan yang bertujuan untuk membangkitkan kesadaran/pengertian dan kepekaan pada warga masyarakat terhadap perkembangan sosial dan ekonomi sehingga pada akhirnya warga masyarakat memiliki kemampuan untuk memperbaiki dan meningkatkan kedudukannya dalam masyarakat, atau menjadi masayarakat yang berdaya khususnya untuk para pemuda (Sunarsi et al., 2019). Kesimpulannya adalah bahwa seorang pemuda harus memiliki jiwa 
dan sikap metal yang bisa membawa ia menciptakan sebuah iklim perubahan kearah yang lebih baik dan memiliki kemampuan sosialisasi ditengah kehidupan dimasyarakat agar ia mampu memecahkan sebuah polemik dan mampu beradaptasi dengan kehidupan social dan memberdayakan pendidikan dalam masyarakat.

Karang Taruna merupakan salah satu wadah organisasi pemuda di RW 03 Desa Cisauk, Kecamatan Cisauk Kabupaten Tangerang banten. Latar belakang pendidikan pemuda karang taruna tersebut yang kebanyakan adalah lulusan SLTA dan sebagian kecil baru lulus dari perguruan tinggi sehingga dengan adanya pelatihan keterampilan teknik sablon ini dapat menambah pengetahuan dan keterampilan bagi pemuda karang taruna sehingga diharapkan dapat menjadi bekal untuk lebih mudah mendapatkan pekerjaan serta dapat membuka peluang usaha dengan membuat produk-produk industri kreatif dengan keterampilan teknik sablon.

Pemberdayaan pemuda karang taruna sebagai anggota masyarakat dan masih tergolong sebagai tenaga kerja produktif sangat penting dilakukan, bertujuan untuk menumbuhkan kesadaran dan kemandirian dalam berusaha, sekaligus memperluas lapangan kerja guna meningkatkan pendapatan keluarga dalam usaha mencapai keluarga yang bahagia dan sejahtera. Dalam kaitannya dengan upaya untuk membina dan mengembangkan potensi keluarga dan daerah, dapat dilakukan melalui berbagai alternatif kegiatan, diantaranya berupa pelatihan teknik sablon manual. Banyak sekali yang dapat dikembangkan dari keterampilan sablon manual ini, salah satunya dapat membuat sablon di T-Shirt yang dapat dikreasikan dengan berbagai desain yang dapat meningkatkan nilai jual dari produk tersebut. Alat produksi yang digunakan dalam proses pembuatannya tidaklah banyak dan rumit layaknya pabrikpabrik besar. Alternatif ini dipilih mengingat pemuda karang taruna di wilayah ini sangat membutuhkan pengetahuan dan keterampilan yang dapat dijadikan bekal untuk merintis usaha dan mereka sebelumnya belum pernah mendapatkan latihan keterampilan ini. Peluang pemasarannya sangat terbuka lebar karena semakin banyaknya peminat T-shirt dan para penggiat bisnis mulai menyadari bahwa T-shirt dapat menjadi medium promosi yang amat efektif serta efesien sehingga dapat menjadi peluang bisnis.

Pembinaan ini diharapkan dapat melengkapi wawasan pengetahuan dan keterampilan pemuda karang taruna dapat dikembangkan untuk menciptakan produkproduk industri kreatif dari teknik sablon manual ini sehingga dapat menciptakan lapangan kerja baru serta dapat meningkatkan tingkat ekonomi.

Kewirausahaan adalah suatu kemampuan untuk mengelola sesuatu yang ada di dalam diri seseorang untuk dimanfaatkan dan ditingkatkan agar lebih optimal (baik) sehingga bisa meningkatkan taraf hidup di masa mendatang (Hadiyati, 2011). Salah satu faktor pendorong pertumbuhan kewirausahaan disuatu negara terletak pada peranan universitas melalui penyelenggaraan pendidikan kewirausahaan. Oleh karena itu, perlu dibina kepribadian individu yang sangat mempengaruhi keberhasilan usaha.Dengan memiliki jiwa pemimpin, siap mental untuk menghadapi segala resiko dan tantangan dalam hidupnya (Tawas \& Djodjobo, 2014).

Melalui penerapan teknologi tepat guna yang sederhana dalam pelatihan ini, diharapkan dapat diperoleh pemberdayaan masyarakat dengan peningkatan keterampilan yang bermanfaat. Teknologi sederhana ini dapat diterapkan oleh masyarakat secara umum. Teknologi ini juga diharapkan menjadi pemicu tumbuhnya semangat kewirausahaan serta dapat mengebangkan industri kreatif.

Keahlian masyarakat sesudah adanya transfer metode pelatihan pembuatan sablon diharapkan: (i) mampu memahami cara pembuatan sablon manual; (ii) mampu membuat kreasi kerajinan dengan teknik sablon; (iii) mampu menjadikan sablon sebagai terobosan untuk menciptakan kreatifitas seni dan menjadikan sablon sebagai UMKM; (v) mampu menghitung keuntungan yang dapat diperoleh dengan memanfaatkan peluang wirausaha. Dari kegiatan yang dilakukan, masyarakat memperoleh luaran produk barang, berupa keterampilan mengenai teknik sablon manual sehingga diharapkan dapat membuat 
sablon sendiri dan sebagai modal untuk menciptakan usaha ekonomi kreatif.

Kegiatan pengabdian masyarakat meliputi identifikasi permasalahan yang muncul pada masyarakat sesuai dengan kompetensi masyarakat bersangkutan.

Permasalahan tersebut yang selanjutnya dikaji dan dicarikan solusi. Metode pendekatan untuk dapat menyelesaikan permasalahan dalam kegiatan ini menggunakan metode Participatory Action Research (PAR). Solusi yang ditawarkan pada kegiatan kewirausahaan pada masyarakat ini berupa pemberian penyuluhan dengan materi yang telah ditentukan.

Bahan-bahan pembuatan sablon dapat dengan mudah ditemukan di toko kimia atau toko sablon terdekat. Bahan dasar pembuatan sablon meliputi pengetal, latex binder dan pigment warna. Dalam pelatihan pembuatan sablon dapat berjalan dengan lancar sesuai dengan yang direncanakan. Kegiatan ini dapat meningkatkan pengetahuan dan keterampilan dalam pembuatan sablon manual yang dapat digunakan sebagai tambahan ketrampilan untuk menciptakan produk kerajinan industri kreatif yang dapat dikomersilkan sehingga dapat menciptakan peluang usaha. Berdasarkan latar belakang di atas, pengusul pengabdian kepada masyarakat tertarik untuk berkontribusi membangun organisasi para pemuda di RW 03 Desa Cisauk, Kecamatan Cisauk, Kabupaten Tangerang, Banten dengan menumbuhkan produktivitas mereka melalui Penyuluhan Dan Pelatihan Keterampilan Sablon Pigment Pasta Manual di Karang Taruna RW 03 Desa Cisauk.

\section{METODE}

Obyek pada kegiatan pengabdian kepada masyarakat ini pada pemuda Karang Taruna RW 03 desa Cisauk, Kecamatan Cisauk Kabupaten Tangerang Banten. Dimana para pemuda Latar belakang pendidikan pemuda karang taruna tersebut yang kebanyakan adalah lulusan SLTA dan sebagian kecil baru lulus dari perguruan tinggi sehingga hampir semua dari mereka sedang mencari pekerjaan. Kita tahu bahwa di negara ini penggangguran setiap tahun nya bertambah dan ditambah lagi dengan adanya kasus Pandemi yang sudah hampir satu tahun hidup berdampingan dengan kita. Dari hal itu salah satu cara untuk tetap bertahan hidup adalah menjadikan diri kita dan juga warga masyarakat mampu berinovasi dan mampu membaca peluang peluang bisnis yang ada yang dapat menghasilkan pundi pundi rupiah untuk tetap dapat bertahan hidup.

Ilmu ekonomi dapat didefinisikan sebagai ilmu yang mempelajari penggunaan sumber daya yang terbatas oleh individu dan masyarakat untuk memenuhi kebutuhan konsumsinya dengan berbagai upaya memproduksi barang dan jasa. Sementara ilmu ekonomi belajar tentang perilaku individu dan masyarakat dalam menentukan pilihan untuk memanfaatkan sumber daya sebagai upaya meningkatkan kualitas hidup. Dari kedua pendapat tersebut dapat disimpulkan bahwa ilmu ekonomi mempelajari bagaimana individu dan masyarakat menggunakan sumber daya yang terbatas untuk memenuhi kebutuhannya.

Ekonomi kreatif merupakan konsep yang menitikberatkan pengembangan nilai tambah suatu barang melalui kreativitas dan inovasi untuk menggerakkan ekonomi. Juga merupakan pengembangan bakat individu yang berdaya kreasi dan daya cipta berdasarkan keterampilan dan kreativitas yang dimiliki (Silvia \& Permana, 2018). Definisi ekonomi kreatif menurut Departemen Perdagangan RI yaitu industry kecil dari pengembangan bakat melalui kreativitas dan keterampilan untuk menciptakan lapangan pekerjaan guna kesejahteraan.

Yang menjadi problem dalam usaha sablon kaos adalah biaya produksi yang cukup tinggi ketika pemesan dalam jumlah kecil, karena pada dasarnya produksi kaos sablon ketika pemesanan dalam jumlah besar bias menekan biaya produksi. Kebalikannya ketika pemesanan dalam jumlah kecil akan meningkatkan jumlah produksi. Sifat bahan sablon adalah ketika pemakaian dalam jumlah besar dan menggunakan desain yang sama maka pemakainya akan lebih irit. Sablon kaos adalah teknik mencetak gambar, foto, karikatur, typography dan berbagai hasil desain lainnya ke permukaan kaos. Artinya inti dari pembuatan kaos selanjutnya selain memikirkan bahan adalah desain yang akan 
disablon ini. Karena pentingnya peran sablon dalam pembuatan kaos, maka banyak sekali bisnis sablon manual untuk kaos bermunculan dan saling bersaing. Perkembangan bisnis fashion yang ditandai dengan maraknya pertumbuhan factory outlet maupun usaha distro di seluruh penjuru nusantara, ternyata menjadi salah satu pemicu meningkatnya permintaan jasa sablon di kalangan masyarakat. Ramainya permintaan pasar dan besarnya prospek bisnis yang dijanjikan, membuat sebagian besar orang mulai tertarik menekuni usaha sablon, baik itu sablon manual ataupun dengan menggunakan sistem sablon digital yang belakangan ini mulai diperkenalkan para pelaku usaha.

Home industri merupakan bagian terkecil dari pengelompokan industri berdasarkan kapasitas pekerja, dimana katagori home industri hanya memiliki 1- 4 orang dengan aset dan modal belum bisa ditentukan. Secara umum pelaku home industri yang menjadi permasalahan adalah memulai berwirausaha, karena untuk menjadi wirausahawan tidak cukup hanya bermodalkan tekat menjadi wirausahawan tetapi butuh komitmen dan motivasi untuk menjadi wirausahawan. Karena untuk merintis usaha atau membuka usaha home indutri tidaklah semudah membalikan telapak tangan. Jatuh bangun dalam usaha itu hal yang sangat wajar, maka dari itu butuh sumber daya manusia yang berdedikasi, ulet, pantang menyerah, pekerja keras dan berani mengambil risiko. agar home industri nya tetap eksis.

Kegiatan pengabdian kepada masyarakat dari tim Dosen Teknik Industri Universitas Pamulang hadir di masyarakat pemuda Karang Taruna RW 03 Desa Cisauk, Kecamatan Cisauk, Kabupaten Tangerang, Banten, berbagi pengetahuan dan wawasan dalam kemasan kegiatan memberikan penyuluhan tentang wirausaha home industri untuk meningkatkan ekonomi keluarga dengan penyuluhan dan pembuatan cetak sablon manual. Penyuluhan yang bertujuan menumbuhkan jiwa wirausaha di kalangan pemuda ini semata-mata untuk memberikan kegiatan positif bagi pemuda agar waktu luangnya tidak sia-sia. Penyuluhan wirausaha home industri untuk meningkatkan ekonomi keluarga. Penyuluhan ini hadir untuk memberikan pengetahuan, wawasan dan peluang yang sangat potensial dikembangkan, karena bahan bakunya murah dan mudah diperoleh. Tetapi untuk kegiatan positif yang lebih produktif sehingga dapat meningkatkan ekonomi keluarga. Tim pengusul pengabdian kepada masyarakat berharap respon dan antusias pemuda Karang Taruna RW 03 Desa Cisauk, Kecamatan Cisauk, Kabupaten Tangerang, Banten, dapat menerima pembaharuan guna membangun desanya. Sehingga kegiatan pengabdian kepada masyarakat tidak hanya berhenti pada kegiatan penyuluhan ini tetapi dapat berkelanjutan sesuai kebutuhan masyarakat. Selain dapat mengurangi angka pengangguran, meningkatkan ekonomi masyarakat juga dapat menjadi peluang usaha kekinian (Pengabdian, 2018).

\section{HASIL DAN PEMBAHASAN}

Pelaksanaan kegiatan yang akan dilakukan untuk mengatasi permasalahan adalah sebagai berikut (Silvia \& Permana, 2018):

1. Penyuluhan.

Materi penyuluhan adalah wirausaha dan peluang usaha industri kreatif, prinsip dasar pembuatan pasta/cat sablon, pengerjaan sablon manual dan pemasaran produk. Tujuan penyuluhan ini adalah memberikan ilmu dan wawasan baru kepada remaja-remaja karang taruna tentang wirausaha dan peluang usaha industri kreatif, sehingga terbuka pikiran serta tumbuh minat dan motivasi dalam diri mereka untuk berwirausaha. Disamping itu juga diberikan materi tentang prinsip dasar pembuatan pasta/cat sablon manual, pengerjaan sablon manual dan pemasaran produk, bertujuan agar mitra mengetahui cara pembuatan pasta/cat sablon, cara menyablon dan strategi pemasaran produk. Penyuluhan ini disampaikan dalam bentuk ceramah dan tanya jawab kepada peserta. 


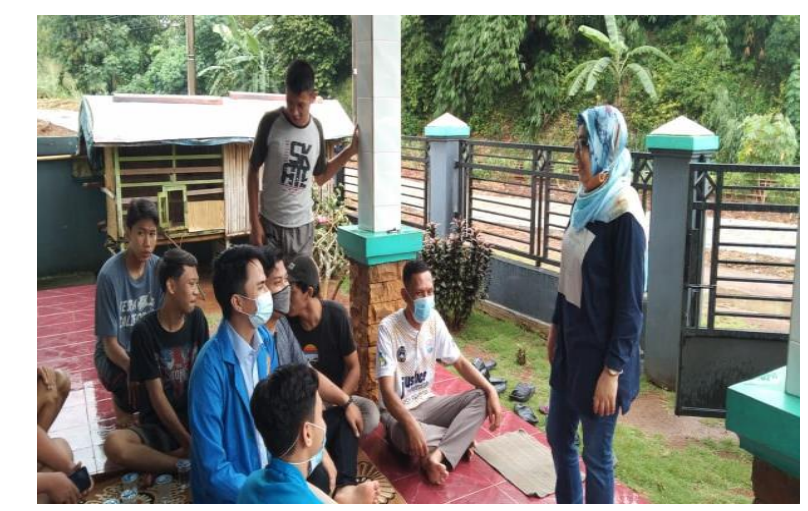

Sumber: Dokumentasi kegiatan PKM, Desember 2020

Gambar 1 Penyuluhan Keterampilan Sablon Pigment Pasta Manual

\section{Pelatihan}

Materi pelatihan adalah cara pembuatan pasta/cat sablon manual serta bagaimana cara menyablon. Kegiatan ini bertujuan untuk memberikan keterampilan tentang cara produksi pasta/cat sablon, cara menyablon dan pemasaran produk. Pelatihan tersebut disampaikan dalam bentuk ceramah yang dilanjutkan dengan eksperimen langsung dan tanya jawab tentang cara pembuatan dan pengerjaan penyablonan tersebut. Pelatihan dilaksanakan sampai semua peserta memahami cara penyablonan yang benar dan mempraktekkan sendiri.

3. Prosedur kegiatan

a. Kegiatan pengabdian ini meliputi: Koordinasi dengan mitra, terkait dengan penyusunan jadwal kegiatan;

b. Persiapan penyuluhan dan pelatihan;

c. Penyuluhan tentang wirausaha dan peluang usaha industry kreatif;

d. Penyuluhan tentang prinsip dasar pembuatan pasta/cat sablon;

e. Penyuluhan tentang pembuatan desain gambar untuk screen sablon;

f. Penyuluhan tentang proses penyablonan;

g. Pembinaan pasca kegiatan.

4. Partisipasi Mitra Partisipasi mitra dalam pelaksanaan kegiatan ini adalah partisipasi aktif, dari mulai perencanaan kegiatan, penyusunan jadwal penyuluhan dan pelatihan. Partisipasi mitra akan dievaluasi. Evaluasi akan dilaksanakan selama dan setelah pelaksanaan kegiatan penyuluhan dan pelatihan. Selama pelaksanaan kegiatan dilakukan evaluasi dengan metode pengamatan langsung oleh Tim Pengabdian. Sedangkan setelah pelaksanaan kegiatan dilakukan evaluasi dengan metode pengamatan terhadap hasil kegiatan dan metode angket. Kriteria evaluasi meliputi kasadaran dan antusiasme peserta penyuluhan dan pelatihan dalam mengikuti kegiatan serta tingkat kemahiran peserta dalam mempraktekkan sendiri mengenai penyablonan yang telah diajarkan.

Kegiatan pengabdian ini dilakukan di pemuda Karang Taruna RW 03 Desa Cisauk, Kecamatan Cisauk Kabupaten Tangerang Banten. Kegiatan yang dilakukan adalah sebagai berikut:

1. Koordinasi dengan pihak-pihak yang terkait

Koordinasi dengan mitra yaitu Ketua RW 03. Pada kegiatan ini tim pengabdian dan mitra membahas tentang kegiatan yang akan dilaksanakan, tempat dan waktu pelaksanaan penyuluhan dan pelatihan. Pada pertemuan ini ada beberapa hal yang disepakati, yaitu kegiatan sosialisasi kegiatan, waktu dan tempat pelaksanaan penyuluhan, serta waktu dan tempat pelaksanaan pelatihan pembuatan pasta/cat sablon dan proses penyablonan (Supriyadi et al., 2020).

2. Persiapan penyuluhan dan pelatihan

Persiapan kegiatan ini berupa penentuan formula pasta/cat sablon, pembuatan modul penyuluhan dan pelatihan. Modul penyuluhan berisi materi dasar tentang wirausaha dan peluang usaha industri kreatif, prinsip dasar pembuatan produk, pengerjaan sablon dan pemasaran produk. Produk berupa hasil sablon pada kain. Modul pelatihan berisi tentang bahan-bahan, 
alat-alat dan cara pembuatan pasta/cat sablon. Pada persiapan pelatihan, Tim pengabdian melakukan uji coba resep pembuatan pasta/cat sablon, sehingga didapatkan komposisi yang tepat dan memberikan hasil optimal.

Berikut adalah tahapan proses pembuatan Cetak Sablon secara manual. Ada 2 tahapan yang dilakukan, tahapan yang pertama adalah:

1. Tahapan pembuatan pasta/cat sablon.

Larutan A (sebagai larutan induk) dibuat dengan mencampurkan 2.5gram Acrylic polymer thickener (pengental) dalam satu wadah (ember) dan 0.5gram larutan ammonia serta zat pengawet kemudian tambahkan dengan air sebanyak 100 cc. Diaduk sampai kedua bahan tersebut larut dengan air dan mengental.

a. Tahapan penambahan pigment warna dan latex binder.

1) Pigment warna. Penambahan zat pewarna (pigment) adalah untuk memberi warna pada pasta sesuai dengan desain yang diinginkan.

2) Latex Binder. Penambahan latex binder adalah untuk mengikat pigment warna ke material/kain yang akan disablon, dosis penambahan latex binder tergantung dosis pigment yang digunakan dengan perbandingan pigment: latex $=1: 3$.

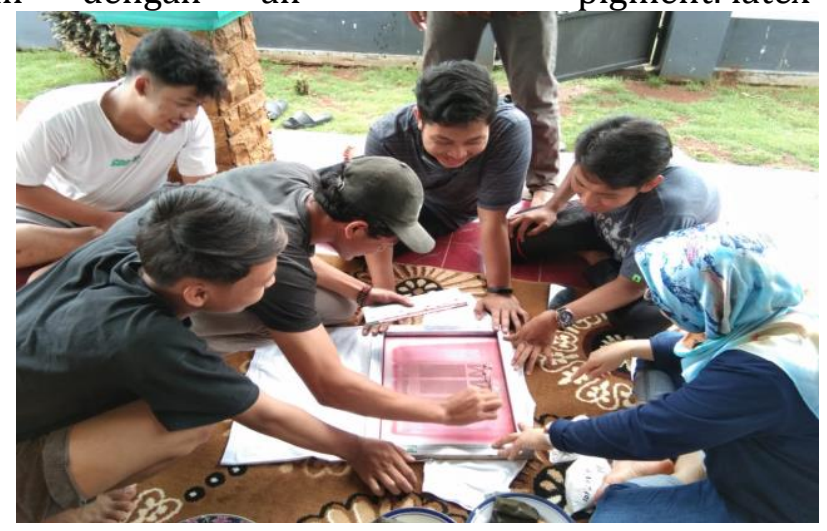

Sumber: Dokumentasi kegiatan PKM, Desember 2020

Gambar 2. Penyuluhan Keterampilan Sablon Pigment Pasta Manual

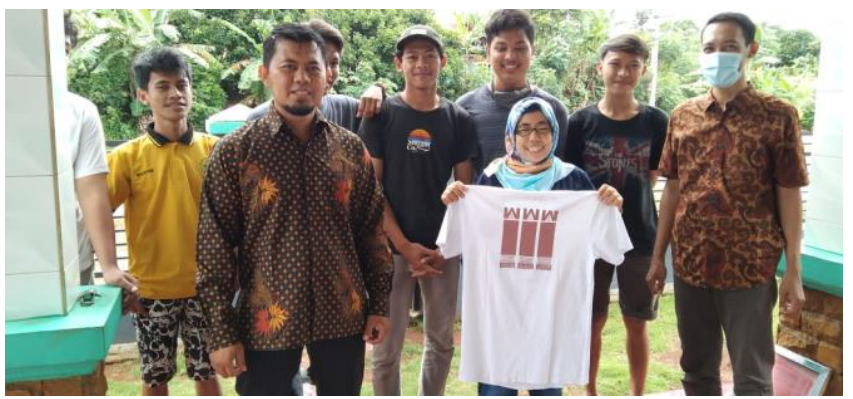

Sumber: Dokumentasi kegiatan PKM, Desember 2020

Gambar 3. Hasil Keterampilan Sablon Pigment Pasta Manual

\section{Pembelian alat dan bahan}

Alat yang dibutuhkan pada pelatihan pembuatan pasta/cat sablon antara lain baskom kecil, pengaduk kayu, sendok, gelas ukur, masker, sarung tangan, kain lap, timbangan, wadah plastik kecil, wadah plastik besar, screen sablon, rakel, lakban bening, sikat plastik, label.

\section{lain: Acrylic polymer thickener}

(pengental), latex binder, pigment warna, larutan ammonia, aquades (Mubarat \& Iswandi, 2018).

3. Pelaksanaan Penyuluhan.

Penyuluhan diadakan di RW 03

Desa Cisauk, Kecamatan Cisauk, Kabupaten Tangerang, Banten, dilaksanakan hari minggu, 13 Desember 2020. Materi yang disampaikan adalah wirausaha dan peluang usaha industri kreatif, prinsip dasar penyablonan. 
4. Pelaksanaan Pelatihan

Pelatihan diberikan dalam bentuk ceramah yang dilanjutkan dengan eksperimen langsung dan tanya jawab. Praktek cara pembuatan pasta pigment sablon dan pelatihan proses penyablonan. Remaja karang taruna dibagi dalam beberapa kelompok, kemudian dengan dibimbing Tim pengabdian mempraktekkan sendiri pembuatan produk tersebut. Pelatihan dilaksanakan sampai semua peserta dapat mempraktekkan sendiri (Pramono \& Hilmy, 2019).

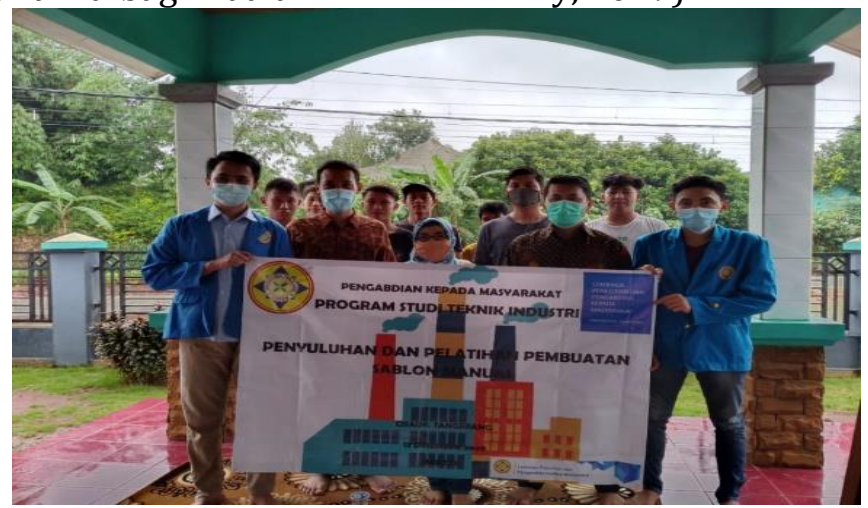

Sumber: Dokumentasi kegiatan PKM, Desember 2020

Gambar 4. Pelaksanaan PKM Keterampilan Sablon Pigment Pasta Manual

\section{PENUTUP}

Pelaksanaan kegiatan pengabdian masyarakat oleh lembaga penelitian dan pengembangan masyarakat (LPPM) Universitas Pamulang yang dilakukan oleh dosen-dosen program studi Pendidikan Ekonomi dan Manajemen telah berjalan dengan lancar dan mendapat sambutan hangat dari tempat pelaksanaan kegiatan ini yaitu para anggota karang taruna Kelurahan Pamulang Barang. Dengan ada kegiatan ini menjadikan para anggota karang taruna di lingkungan Kelurahan Pamulang Barat dapat memahami pentingnya pelatihan dasar kepemimpinan milenial.

Selama kegiatan berlangsung peserta penyuluhan memberikan tanggapan yang sangat baik, hal ini dapat dilihat dari dukungan dan atusiasme mereka dalam setiap kegiatan yang diadakan. Selain itu harapan kami dengan pengabdian ini dapat membuka wawasan dari para anggota karang taruna, sehingga tidak hanya memberikan tambahan pengetahuan tetapi juga dapat diterapkan khususnya dalam menerapkan kemampuan berorganisasi. Selain itu diharapkan juga dapat membantu dan meningkatkan kepemimpinan mereka dengan pendekatan terkini atau milenial.

\section{DAFTAR PUSTAKA}

Arikunto, Suharsimi, 2002. Prosedur Penelitian: Suatu Pendekatan Praktek. Jakarta: Rineka Cipta. As'ad, Moh., 1998. Psikologi Industri. Yogyakarta: Liberty.

Dessler, Gary, 1992. Manajemen Personalia. Jakarta: Erlangga. Fatherius, Achmad, 1997. Hubungan Lingkungan Internal dan Eksternal terhadap Produktivitas Karyawan Perusahaan Tekstil di PT. Pabrik Cambries Primissima. Yogyakarta. Yogyakarta: Pascasarjana UGM.

Gibson, James L., $1987 . \quad$ Kepemimpinan Organisasi: Perilaku dan Struktur. Jakarta: Erlangga. Ghozali, Imam, 2001. Aplikasi Analisis Multivariate dengan Program SPSS. Semarang: Universitas Diponegoro Gujarati, Damodar, 1995. Basic Econometrics, ed. 3. Boston:

McGraw Hill. Hasibuan, Malayu S. P., 2001. Manajemen Sumber Daya Manusia. Jakarta: Bumi Aksara. Kartono, Kartini, 1998. Pemimpin dan Kepemimpinan: Apakah Pemimpin Abnormal Itu? Jakarta: RajaGrafindo Persada 